\title{
Pengaruh Perlakuan pH dan Suhu terhadap Stabilitas Ekstrak Alga Merah (Gracilaria sp.) sebagai Pewarna Alami
}

The Effect of $\mathrm{pH}$ and Temperature on Red Algae (Gracilaria sp.) Extract Stability as Natural Dyes

Odilia Keron, Luh Putu Wrasiati*, Ida Bagus Wayan Gunam

PS Teknologi Industri Pertanian, Fakultas Teknologi Pertanian, Universitas Udayana, Kampus Bukit Jimbaran, Badung, Kode pos : 80361; Telp/Fax : (0361) 701801

Diterima 02 Agustus 2021 / Disetujui 31 Agustus 2021

\begin{abstract}
Phycoerytrin is a red pigment found in red algae. Red algae Gracilaria sp. potential to be a source of natural dye because it contains phycoerythrin. Phycoerythrin is unstable to light, $\mathrm{pH}$, and temperature. The purpose of this study was to determine the effect of $\mathrm{pH}$ and temperature on the stability of the dye extract from the red algae Gracilaria sp. and determine the $\mathrm{pH}$ and temperature that best maintain the constancy of the red algae Gracilaria sp. extract during storage. The design in this study used a completely randomized design with two factors, namely $\mathrm{pH}$ and temperature. First factor was the $\mathrm{pH}$ treatment which consist of three levels namely $\mathrm{pH} 4, \mathrm{pH} 7$ and $\mathrm{pH} 10$ and second factor was initial temperature consist of two levels, namely $4 \pm 2{ }^{\circ} \mathrm{C}$ and $28 \pm 2^{\circ} \mathrm{C}$. The results showed that $\mathrm{pH}$ had a very significant effect $(P<0.01)$ on the total phycoerythrin, brightness $\left(L^{*}\right)$, redness $\left(a^{*}\right)$ and yellowness $\left(b^{*}\right)$ at weeks $2,3,4$. Temperature treatment has a very significant effect on the total phycoerythrin and brightness $\left(L^{*}\right)$ at weeks 3 and 4 , as well the level redness $\left(a^{*}\right)$ and the level yellowness $\left(b^{*}\right)$ at weeks 2,3 and 4 . At pH 4 and cold temperature $\left(4 \pm 2{ }^{\circ} \mathrm{C}\right)$ were the best treatments to maintain the stability of the red algae Gracilaria sp. extract during storage. They had the lowest decrease in phycoerythrin levels and redness ( $\left.a^{*}\right)$, and had the smallest increase in brightness $\left(L^{*}\right)$ and yellowness $\left(b^{*}\right)$. Extract that were stored for 4 weeks with $\mathrm{pH} 4$ and temperature $4 \pm 2{ }^{\circ} \mathrm{C}$ treatment had decrease in total phycoerythrin, increase in brightness $\left(L^{*}\right)$, decrease in redness $\left(a^{*}\right)$, and increase in yellowness $\left(b^{*}\right)$ successively was $13.04 \%, 0.47 \%$, 6.58\%, dan $3.50 \%$.
\end{abstract}

Keywords : Gracilaria sp. extract, phycoeriythrin, $p H$, temperature, stability.

\begin{abstract}
ABSTRAK
Fikoeritrin merupakan pigmen berwarna merah yang terdapat dalam alga merah. Alga merah Gracilaria sp. berpotensi menjadi sumber pewarna alami. Fikoeritrin memiliki sifat yang tidak stabil terhadap cahaya, $\mathrm{pH}$ dan suhu. Tujuan dari penelitian ini adalah mengetahui pengaruh $\mathrm{pH}$ dan suhu terhadap stabilitas ekstrak pewarna dari alga merah Gracilaria sp. selama penyimpanan serta menentukan $\mathrm{pH}$ dan suhu terbaik yang dapat mempertahankan warna merah pada ekstrak tersebut. Rancangan dalam penelitian ini menggunakan Rancangan Acak Lengkap dengan dua faktor yakni $\mathrm{pH}$ dan suhu. Faktor I adalah perlakuan $\mathrm{pH}$ yang terdiri dari 3 taraf yaitu $\mathrm{pH} 4,7$ dan 10 . Faktor II adalah suhu yang terdiri dari dua taraf yaitu $4 \pm 2^{\circ} \mathrm{C}$ dan $28 \pm 2^{\circ} \mathrm{C}$. Hasil penelitian menunjukkan bahwa $\mathrm{pH}$ berpengaruh sangat nyata $(\mathrm{p}<0,01)$ terhadap total fikoeritrin, tingkat kecerahan $\left(L^{*}\right)$, tingkat kemerahan $\left(a^{*}\right)$ dan tingkat kekuningan $\left(b^{*}\right)$ pada minggu ke-2, 3, 4. Perlakuan suhu berpengaruh sangat nyata terhadap kadar total fikoeritrin dan tingkat kecerahan $\left(L^{*}\right)$ pada minggu ke-3 dan 4 ,
\end{abstract}

\footnotetext{
*Korespondensi Penulis:

Email:wrasiati@unud.ac.id
} 
serta tingkat kemerahan $\left(a^{*}\right)$ dan tingkat kekuningan $\left(b^{*}\right)$ pada minggu ke-2, 3, dan 4. Perlakuan pH 4 dan suhu dingin $\left(4 \pm 2^{\circ} \mathrm{C}\right)$ merupakan perlakuan terbaik untuk mempertahankan stabilitas ekstrak alga merah Gracilaria sp. selama penyimpanan karena memiliki penurunan kadar fikoeritrin dan penurunan tingkat kemerahan $\left(a^{*}\right)$ terkecil, serta memiliki kenaikan tingkat kecerahan $\left(L^{*}\right)$ dan tingkat kekuningan $\left(b^{*}\right)$ terkecil. Ekstrak yang mengalami penyimpanan 4 minggu dengan perlakuan $\mathrm{pH} 4$ dan suhu $4 \pm 2^{\circ} \mathrm{C}$ memiliki persentase penurunan kadar fikoeritrin, kenaikan nilai kecerahan $\left(L^{*}\right)$, penurunan nilai kemerahan $\left(a^{*}\right)$ dan kenaikan nilai kekuningan $\left(b^{*}\right)$ berturut-turut adalah $13,04 \%, 0,47 \%, 6,58 \%$, dan 3,50\%.

Kata kunci : ekstrak Gracilaria sp., fikoeritrin, $\mathrm{pH}$, suhu, stabilitas warna

\section{PENDAHULUAN}

Gracilaria sp. merupakan salah satu jenis rumput laut golongan alga merah (Rhodophyta) yang banyak dibudidayakan di Indonesia karena memiliki nilai ekonomis tinggi sehingga mampu menjadi salah satu komoditas ekspor (Alamsjah et al., 2010). Penelitian Niu et al. (2006) menunjukan bahwa warna merah pada rumput laut Gracilaria sp. dapat diekstrak menjadi pewarna alami untuk dapat menggantikan pewarna sintesis. Zat pewarna dapat ditemukan dalam rumput laut merah karena mengandung pigmen fikobilin yang terdiri dari fikoeritrin dan fikosianin (Romay et al., 2000; Suhartono dan Angka, 2000). Pigmen fikoeritrin dapat diperoleh melalui ekstraksi menggunakan metode maserasi menggunakan pelarut polar.

Ekstraksi dengan pelarut adalah proses pemisahan suatu senyawa yang dilakukan dengan cara melarutkan campuran dalam pelarut tertentu. Sudhakar et al. (2015) melakukan ekstraksi dengan pelarut yang berbeda yaitu buffer fosfat, aquades, dan air laut. Hasil menunjukan ekstrak aquades memiliki kandungan fikoeritrin tertinggi yakni sebesar $0,038 \mathrm{mg} / \mathrm{mL}$ diikuti dengan ekstrak buffer fosfat dan air laut sebesar $0,028 \mathrm{mg} / \mathrm{mL}$ dan $0,024 \mathrm{mg} / \mathrm{mL}$. Metode maserasi merupakan salah satu metode ekstraksi dengan cara merendam bahan dengan pelarut polar atau non-polar dalam waktu tertentu, sehingga diperoleh filtrat dengan residu bahan yang dimaserasi (Septiana dan Asnani, 2012). Metode maserasi dipilih untuk mengekstrak pigmen fikoeritrin karena sifat fikoeritrin yang mudah terdegradasi bila terpapar intensitas cahaya tinggi dan panas secara langsung (Agustini, 2013).

Penyimpanan pada $\mathrm{pH}$ dan suhu tertentu mempengaruhi kestabilan terhadap ekstrak Gracilaria sp. Berdasarkan penelitian Indriyani et al. (2018) tentang stabilitas karotenoid ekstrak pewarna buah pandan (Pandanus tetoris) pada suhu dan $\mathrm{pH}$ awal penyimpanan memperoleh hasil perlakuan $\mathrm{pH}$ berpengaruh sangat nyata pada setiap minggunya terhadap total karotenoid. Ekstrak pewarna karotenoid buah pandan paling stabil pada perlakuan pH 7 (netral) dan pada penyimpanan suhu dingin $\left(4 \pm 3^{\circ} \mathrm{C}\right)$ selama 4 minggu penyimpanan dengan persentase penurunan total karotenoid sebesar 34,29\%.

Berdasarkan penelitian Kawsar et al. (2011) fikoeritrin stabil disimpan pada $\mathrm{pH} 4$ sampai 10 dan tahan pada suhu dibawah $40^{\circ} \mathrm{C}$, tetapi sensitif terhadap cahaya (Munier et al., 2014). Rentang pH dan suhu dari penelitian Kawsar et al. (2011) dan Munier et al. (2014) masih terlalu besar untuk aplikasi penyimpanan dan aplikasi pada produk pangan. Berdasarkan hal tersebut, maka perlu dilakukan penelitian mengenai pengaruh perlakuan $\mathrm{pH}$ dan suhu terhadap stabilitas ekstrak alga merah (Gracilaria sp.) agar mampu dimanfaatkan sebagai sumber pewarna alami.

\section{METODE PENELITIAN}

\section{Bahan dan Alat}

Bahan yang digunakan dalam penelitian ini yaitu alga merah Gracilaria sp., aquades, buffer fosfat $\mathrm{pH} 4, \mathrm{pH}$ 7, dan $\mathrm{pH} 10$.

Peralatan yang digunakan dalam 
penelitian ini antara lain oven (Blue $M$ ), blender (Miyako), mesin grinder (Damiji model: FFC-15), timbangan analitik (Shimadzu), spektrofotometer (Biochrome SN 133467), rotary evaporator vacuum, vortex (Barnstead Thermolyne Maxi Mix II), ayakan 60 mesh (Retsch), color reader (Colorimeter PCE-CSM1, PCE-CSM 2 and PCE-CSM 4) dan alat-alat gelas.

\section{Pelaksanaan Penelitian}

\section{Pembuatan bubuk Gracilaria sp.}

Gracilaria sp. yang digunakan pada penelitian ini yaitu yang berwarna merah dengan panjang talus $10-20 \mathrm{~cm}$. Gracilaria sp. yang masih segar dicuci dengan air mengalir dan dikeringanginkan selama 5-6 hari lalu dipotong-potong dan dilanjutkan dengan pengeringan dengan menggunakan oven drier pada suhu $50 \pm 2^{\circ} \mathrm{C}$ selama 3 jam atau sampai mudah dihancurkan. Gracilaria sp. yang telah kering kemudian dihancurkan dengan mesin grinder. Bubuk Gracilaria sp. yang telah halus kemudian diayak dengan ayakan 60 mesh. Bahan yang tidak lolos ayakan diblender kembali hingga lolos ayakan 60 mesh. Kadar air dari bubuk Gracilaria sp. yaitu $15,48 \%$.

\section{Pembuatan ekstrak Gracilaria sp.}

Bubuk Gracilaria sp. ditimbang sebanyak $70 \mathrm{~g}$ dan dimasukkan ke dalam botol kaca berwarna gelap, kemudian ditambahkan pelarut aquades sebanyak $700 \mathrm{~mL}$. Perbandingan bubuk Gracilaria sp. dengan pelarut aquades yaitu 1:10 (b/v). Proses ekstraksi dilakukan dengan metode maserasi menggunakan suhu ruangan $\left(28 \pm 2^{\circ} \mathrm{C}\right)$ dan lama maserasi 10 jam. Selama ekstraksi setiap 6 jam digojog selama 5 menit. Setelah proses maserasi, dilakukan proses penyaringan dengan menggunakan kertas saring sebanyak 2 kali. Penyaringan pertama menggunakan kertas saring kasar yang kemudian menghasilkan filtrat I dan ampas. Ampas kemudian ditambahkan dengan pelarut sebanyak $100 \mathrm{~mL}$, digojog selama 5 menit, dan kemudian disaring dengan menggunakan kertas saring kasar dan kemudian menghasilkan filtrat II. Filtrat I dan II kemudian dicampur dan disaring kembali dengan menggunakan kertas saring Whatman no.1. Filtrat kemudian dievaporasi dengan rotary vacuum evaporator pada suhu $45^{\circ} \mathrm{C}$ dengan tekanan $100 \mathrm{mBar}$ sampai diperoleh ekstrak kental. Ekstrak kental yang diperoleh kemudian ditimbang dan dimasukkan ke dalam wadah sampel yang berwarna gelap.

\section{Uji stabilitas ekstrak Gracilaria sp.}

Ekstrak Gracilaria sp. yang disimpan pada perlakuan $(\mathrm{pH} 4, \mathrm{pH} 7$, dan $\mathrm{pH} 10)$ menggunakan larutan buffer untuk mengatur keasaman. Ekstrak kental ditimbang sebanyak $1 \mathrm{~g}$ dihomogenkan dengan $10 \mathrm{~mL}$ dari masingmasing pelarut kemudian disimpan di dalam botol kaca gelap. Sampel yang telah homogen kemudian disimpan sesuai perlakuan $\left(4 \pm 2^{\circ} \mathrm{C}\right.$ dan $28 \pm 2^{\circ} \mathrm{C}$ ). Perlakuan suhu $4 \pm 2^{\circ} \mathrm{C}$ ekstrak disimpan pada kulkas dan perlakuan suhu $28 \pm 2^{\circ} \mathrm{C}$ ekstrak disimpan pada suhu ruangan, kemudian dilakukan pengamatan setiap minggu selama 4 minggu terhadap intensitas kadar fikoeritrin menggunakan spektofotometer pada panjang gelombang 564 - $730 \mathrm{~nm}$ dan intensitas warna dengan color reader.

\section{Variabel yang diamati}

Variabel yang diamati dalam penelitian ini yaitu kadar total fikoeritrin (Siegelman dan Kycia, 1987; Silveira et al., 2007) dan intensitas warna yang meliputi $L^{*}, a^{*}$ dan $b^{*}$ (Weafer, 1996).

\section{HASIL DAN PEMBAHASAN}

\section{Kadar total fikoeritrin}

Ekstrak Gracilaria sp. minggu ke-0 mempunyai total fikoeritrin sebesar 0,299 $\mathrm{mg} / \mathrm{g}$. Pengamatan uji stabilitas ekstrak pewarna dari alga merah Gracilaria sp. menunjukkan bahwa semua perlakuan $\mathrm{pH}$ dan suhu awal pada penyimpanan ekstrak pewarna 
dari alga merah Gracilaria sp. mengakibatkan penurunan pada total fikoeritrin selama 4 minggu penyimpanan.

Hasil analisis ragam total fikoeritrin menunjukkan bahwa perlakuan $\mathrm{pH}$ berpengaruh sangat nyata $(\mathrm{p}<0,01)$ untuk minggu ke-2, 3, dan 4 serta berpengaruh nyata $(\mathrm{p}<0,05)$ pada minggu ke-1. Perlakuan suhu menunjukan pengaruh sangat nyata $(\mathrm{p}<0,01)$ pada minggu ke-3 dan 4 . Interaksi kedua perlakuan tidak nyata $(\mathrm{p}>0,05)$ pada minggu ke-1, 2 dan 4. Rata-rata total fikoeritrin ekstrak Gracilaria sp. selama penyimpanan dapat dilihat pada Tabel 1.

Tabel 1. Rata-rata total fikoeritrin ekstrak Gracilaria sp. pada perlakuan $\mathrm{pH}$ dan suhu penyimpanan pada minggu ke-1 sampai minggu ke-4

\begin{tabular}{|c|c|c|c|c|c|c|c|}
\hline \multicolumn{4}{|c|}{ Minggu ke-1 } & \multicolumn{4}{|c|}{ Minggu ke-2 } \\
\hline \multirow{2}{*}{$\mathrm{pH}$} & \multicolumn{2}{|c|}{ Suhu } & \multirow{2}{*}{ Rata-rata \pm SD } & \multirow{2}{*}{$\mathrm{pH}$} & \multicolumn{2}{|c|}{ Suhu } & \multirow{2}{*}{ Rata-rata \pm SD } \\
\hline & $4 \pm 2^{\circ} \mathrm{C}$ & $28 \pm 2^{\circ} \mathrm{C}$ & & & $4 \pm 2^{\circ} \mathrm{C}$ & $28 \pm 2^{\circ} \mathrm{C}$ & \\
\hline 4 & 0,280 & 0,270 & $0,275 \pm 0,008^{a}$ & 4 & 0,276 & 0,266 & $0,271 \pm 0,008^{a}$ \\
\hline 7 & 0,269 & 0,260 & $0,264 \pm 0,012^{\mathrm{ab}}$ & 7 & 0,264 & 0,258 & $\begin{array}{l}0,261 \pm \\
0,014^{\mathrm{ab}}\end{array}$ \\
\hline 10 & 0,257 & 0,241 & $0,249 \pm 0,017^{\mathrm{b}}$ & 10 & 0,245 & 0,236 & $0,240 \pm 0,008^{b}$ \\
\hline Rata-rata \pm SD & $\begin{array}{c}0,268 \pm \\
0,019^{\mathrm{a}} \\
\end{array}$ & $\begin{array}{c}0,257 \pm \\
0,012^{\mathrm{a}} \\
\end{array}$ & & $\begin{array}{c}\text { Rata-rata } \pm \\
\text { SD } \\
\end{array}$ & $\begin{array}{c}0,262 \pm \\
0,017^{\mathrm{a}}\end{array}$ & $\begin{array}{c}0,253 \pm \\
0,015^{\mathrm{a}}\end{array}$ & \\
\hline
\end{tabular}

\begin{tabular}{|c|c|c|c|c|c|c|}
\hline \multicolumn{3}{|c|}{ Minggu ke-3 } & \multicolumn{4}{|c|}{ Minggu ke-4 } \\
\hline \multirow{2}{*}{$\mathrm{pH}$} & \multicolumn{2}{|c|}{ Suhu } & \multirow{2}{*}{$\mathrm{pH}$} & \multicolumn{2}{|c|}{ Suhu } & \multirow{2}{*}{ Rata-rata \pm SD } \\
\hline & $4 \pm 2^{\circ} \mathrm{C}$ & $28 \pm 2^{\circ} \mathrm{C}$ & & $4 \pm 2^{\circ} \mathrm{C}$ & $28 \pm 2^{\circ} \mathrm{C}$ & \\
\hline 4 & $0,271 \pm 0,009^{a}$ & $0,249 \pm 0,006^{b}$ & 4 & 0,265 & 0,246 & $0,256 \pm 0,119^{a}$ \\
\hline 7 & $0,247 \pm 0,006^{\mathrm{bc}}$ & $0,248 \pm 0,003^{b c}$ & 7 & 0,230 & 0,220 & $0,225 \pm 0,010^{\mathrm{b}}$ \\
\hline \multirow[t]{2}{*}{10} & \multirow[t]{2}{*}{$0,238 \pm 0,015^{\text {bcd }}$} & \multirow[t]{2}{*}{$0,216 \pm 0,004^{\mathrm{e}}$} & 10 & 0,220 & 0,204 & $0,214 \pm 0,012^{\mathrm{c}}$ \\
\hline & & & $\begin{array}{c}\text { Rata-rata } \pm \\
\text { SD }\end{array}$ & $\begin{array}{c}0,239 \pm \\
0,019^{\mathrm{a}}\end{array}$ & $\begin{array}{c}0,223 \pm \\
0,020^{\mathrm{b}}\end{array}$ & \\
\hline
\end{tabular}

Keterangan: Angka yang diikuti huruf yang berbeda pada kolom dan baris yang sama menunjukan berbeda nyata $(\mathrm{P}<0,05)$. Data merupakan rata-rata dari tiga ulangan pada masing-masing perlakuan

Persentase total fikoeritrin ekstrak Gracilaria sp. selama penyimpanan pada masing-masing perlakuan mengalami penurunan setiap minggunya. Pada minggu ke1 dan ke-2 kadar fikoeritrin ekstrak Gracilaria sp. tidak terjadi perbedaan nyata antara $\mathrm{pH} 4$ dan $\mathrm{pH} 7$ serta tidak berbeda pada perlakuan suhu penyimpanan yang ditandai dengan sedikit berkurangnya warna kemerahan pada ekstrak Gracilaria sp. Pada minggu ke-3 kadar fikoeritrin ekstrak Gracilaria sp. pada perlakuan $\mathrm{pH} 4$ suhu $4 \pm 2^{\circ} \mathrm{C}$ berbeda nyata dengan perlakuan lainnya. Pada minggu ke-4 terjadi perbedaan nyata antara perlakuan $\mathrm{pH}$ dan suhu pada setiap perlakuan. Perlakuan $\mathrm{pH}$ 10 pada suhu $28 \pm 2^{\circ} \mathrm{C}$ menunjukkan penurunan total fikoeritrin terbesar dibandingkan perlakuan lainnya yaitu sebesar $33,11 \%$. Hal ini menunjukkan bahwa pigmen fikoeritrin pada ekstrak pewarna alga merah Gracilaria sp. paling tidak stabil pada perlakuan tersebut. Penelitian serupa juga menunjukan bahwa fikoeritrin dari dari alga merah Rhodymenia palmata stabil pada range $\mathrm{pH} 3,5-9.5$ (Galland-Irmouli et al., 2000), alga merah Polysiphonia urceolata stabil pada range $\mathrm{pH}$ 3,5 - 9,5 (Liu et al., 2009) dan alga merah Porphyra yezoensis (Orta-Ramirez et al., 2000) stabil pada range $\mathrm{pH} 3,5-9,5$. Penambahan $\mathrm{pH}$ dapat menyebab terganggunya sifat elektrostatis dan ikatan hidrogen yang terdapat dalam protein yang dapat menyebabkan perubahan struktur kromofor (Claire, 1992). Saat keadaan $\mathrm{pH}$ di bawah dari 3 dan lebih dari 10 akan mengalami denaturasi protein ditandai dengan hilangnya warna karena protein hanya berfungsi biologis pada nilai pH yang terbatas (Naga et al., 2010; 
Kawsar et al., 2011). Selain itu pigmen fikoeritrin stabil pada penyimpanan dengan kondisi suhu rendah. Seiring dengan peningkatan suhu menyebabkan hilangnya kestabilan pigmen karena penurunan $\alpha$-helix (D'Agnolo et al., 1993). Hal ini sesuai dengan penelitian Rossano (2003) bahwa fikoeritrin dari alga merah $C$. elongate stabil pada suhu $4^{\circ} \mathrm{C}$ yang disimpan dalam kondisi gelap.

\section{Tingkat Kecerahan $\left(L^{*}\right)$}

Nilai $L^{*}$ menyatakan tingkat kecerahan, yaitu tingkat gelap hingga terang dengan rentan nilai $0-100$ (Indrayati et al.2013). Semakin besar nilai $L^{*}$ maka tingkat kecerahan semakin tinggi. Nilai kecerahan
$\left(L^{*}\right)$ minggu ke-0 pada ekstrak pewarna dari alga merah Gracilaria sp. yang diperoleh adalah sebesar 20,80.

Analisis ragam pada nilai kecerahan menunjukkan bahwa perlakuan $\mathrm{pH}$ berpengaruh sangat nyata $(\mathrm{p}<0,01)$ pada minggu ke-2, 3 dan 4 dan berpengaruh tidak nyata $(\mathrm{p}>0,05)$ pada minggu ke-1. Perlakuan suhu menunjukan pengaruh sangat nyata $(\mathrm{p}<0,01)$ pada minggu ke-3 dan 4 serta berpengaruh nyata $(p>0,01)$ pada minggu ke1. Interaksi kedua perlakuan tidak nyata (p>0,05) pada minggu ke-1, 2, 3, dan 4. Ratarata nilai kecerahan $\left(L^{*}\right)$ ekstrak Gracilaria sp. tiap minggunya dapat dilihat pada Tabel 2.

Tabel 2. Rata-rata nilai kecerahan ( $\left.L^{*}\right)$ ekstrak Gracilaria sp. dan laju kenaikan nilai kecerahan pada perlakuan $\mathrm{pH}$ dan suhu penyimpanan pada minggu ke-1 sampai minggu ke-4.

\begin{tabular}{|c|c|c|c|c|c|c|c|}
\hline \multicolumn{4}{|c|}{ Minggu ke-1 } & \multicolumn{4}{|c|}{ Minggu ke-2 } \\
\hline \multirow{2}{*}{$\mathrm{pH}$} & \multicolumn{2}{|c|}{ Suhu } & \multirow{2}{*}{ Rata-rata \pm SD } & \multirow{2}{*}{$\mathrm{pH}$} & \multicolumn{2}{|c|}{ Suhu } & \multirow{2}{*}{ Rata-rata \pm SD } \\
\hline & $4 \pm 2^{\circ} \mathrm{C}$ & $28 \pm 2^{\circ} \mathrm{C}$ & & & $4 \pm 2^{\circ} \mathrm{C}$ & $28 \pm 2^{\circ} \mathrm{C}$ & \\
\hline 4 & 20,58 & 21,73 & $21,157 \pm 0,760^{\mathrm{a}}$ & 4 & 20,67 & 20,74 & $20,708 \pm 0,420^{\mathrm{b}}$ \\
\hline 7 & 21,15 & 21,00 & $21,077 \pm 0,658^{\mathrm{a}}$ & 7 & 21,75 & 21,97 & $21,867 \pm 0,014^{\mathrm{a}}$ \\
\hline 10 & 21,29 & 22,48 & $21,890 \pm 0,904^{\mathrm{a}}$ & 10 & 21,16 & 22,16 & $21,792 \pm 0,008^{\mathrm{a}}$ \\
\hline Rata-rata \pm SD & $\begin{array}{c}21,74 \pm \\
0,017^{\mathrm{a}} \\
\end{array}$ & $\begin{array}{c}21,00 \pm \\
0,015^{\mathrm{a}}\end{array}$ & & Rata-rata \pm SD & $\begin{array}{c}21,19 \pm \\
0,644^{\mathrm{b}}\end{array}$ & $\begin{array}{l}21,71 \pm \\
0,880^{\mathrm{a}}\end{array}$ & \\
\hline \multicolumn{4}{|c|}{ Minggu ke-3 } & \multicolumn{4}{|c|}{ Minggu ke-4 } \\
\hline \multirow{2}{*}{$\mathrm{pH}$} & \multicolumn{2}{|c|}{ Suhu } & \multirow{2}{*}{ Rata-rata \pm SD } & \multirow{2}{*}{$\mathrm{pH}$} & \multicolumn{2}{|c|}{ Suhu } & \multirow{2}{*}{ Rata-rata \pm SD } \\
\hline & $4 \pm 2^{\circ} \mathrm{C}$ & $28 \pm 2^{\circ} \mathrm{C}$ & & & $4 \pm 2^{\circ} \mathrm{C}$ & $28 \pm 2^{\circ} \mathrm{C}$ & \\
\hline 4 & 21,34 & 21,07 & $21,17 \pm 0,008^{b}$ & 4 & 20,90 & 21,71 & $21,308 \pm 0,459^{b}$ \\
\hline 7 & 21,28 & 22,18 & $21,73 \pm 0,012^{\mathrm{ab}}$ & 7 & 21,41 & 22,33 & $21,872 \pm 0,573^{a b}$ \\
\hline 10 & 22,08 & 23,77 & $22,72 \pm 0,017^{\mathrm{a}}$ & 10 & 22,06 & 23,03 & $22,553 \pm 0,774^{\mathrm{a}}$ \\
\hline Rata-rata \pm SD & $\begin{array}{c}21,21 \pm \\
0,871^{\mathrm{b}}\end{array}$ & $\begin{array}{c}22,21 \pm \\
1,032^{\mathrm{a}} \\
\end{array}$ & & Rata-rata \pm SD & $\begin{array}{c}21,45 \pm \\
0,644^{\mathrm{a}}\end{array}$ & $\begin{array}{c}22,36 \pm \\
0,880^{\mathrm{a}} \\
\end{array}$ & \\
\hline
\end{tabular}

Keterangan: Angka yang diikuti huruf yang berbeda pada kolom dan baris yang sama menunjukan berbeda nyata $(\mathrm{P}<0,05)$. Data merupakan rata-rata dari tiga ulangan pada masing-masing perlakuan

Persentase nilai kecerahan $\left(L^{*}\right)$ ekstrak alga merah Gracilaria sp. selama penyimpanan pada masing-masing perlakuan mengalami kenaikan setiap minggunya. Pada minggu ke-1 perlakuan $\mathrm{pH}$ dan suhu tidak mengalami perbedaan. Pada minggu ke-2 perlakuan $\mathrm{pH} 7$ dan $\mathrm{pH} 10$ berbeda dengan perlakuan $\mathrm{pH} 4$ serta perlakuan suhu $4 \pm 2^{\circ} \mathrm{C}$ berbeda dengan perlakuan suhu $28 \pm 2^{\circ} \mathrm{C}$. Pada minggu ke-3 perlakuan $\mathrm{pH} 7$ dan $\mathrm{pH} 10$ tidak mengalami perbedaan nyata tetapi berbedaan nyata pada $\mathrm{pH} 4$ serta pada perlakuan suhu penyimpanan terjadi perbedaan antara suhu $4 \pm 2^{\circ} \mathrm{C}$ dan $28 \pm 2^{\circ} \mathrm{C}$. Pada minggu ke-4 perlakuan $\mathrm{pH} 10$ dan $\mathrm{pH} 4$ mengalami perbedaan nyata serta suhu penyimpanan tidak mengalami perbedaan. Kenaikan nilai kecerahan menunjukkan penurunan kadar fikoeritrin pada ekstrak Gracilaria sp. pH 10 pada suhu $28 \pm 2^{\circ} \mathrm{C}$ menunjukkan kenaikan nilai kecerahan $\left(L^{*}\right)$ terbesar dibanding dengan perlakuan lainnya yaitu sebesar $9,72 \%$. Hal ini menunjukkan bahwa pigmen fikoeritrin pada ekstrak alga merah Gracilaria sp. tidak stabil 
pada perlakuan tersebut karena kadar fikoeritrin yang tinggi memiliki warna yang semakin gelap atau nilai kecerahan $\left(L^{*}\right)$ yang semakin rendah, begitu juga sebaliknya. Hal ini sesuai dengan penelitian Sajilata dan Singhal (2006) dan Gross (1991) yang menyatakan bahwa perubahan warna pada pigmen menunjukkan terjadinya degradasi akibat terpapar pada suhu dan cahaya dengan intensitas tinggi dalam waktu yang cukup lama.

\section{Tingkat Kemerahan $(a *)$}

Nilai kemerahan $\left(a^{*}\right)$ merupakan indikator untuk warna hijau hingga merah. Nilai $a$ yang negatif menunjukkan warna hijau dan nilai $a$ yang positif menunjukkan warna merah (Indriyani et al., 2013). Nilai kemerahan $\left(a^{*}\right)$ minggu ke-0 pada ekstrak pewarna dari alga merah Gracilaria sp. diperoleh sebesar 20,66. Analisis ragam pada nilai kemerahan $\left(a^{*}\right)$ menunjukkan bahwa $\mathrm{pH}$ berpengaruh sangat nyata $(\mathrm{p}<0,01)$ pada minggu ke- 2,3 dan 4 dan bepengaruh tidak nyata pada $(\mathrm{p}>0,05)$ pada minggu ke-1. Perlakuan suhu berpengaruh sangat nyata $(\mathrm{p}<0,01)$ pada minggu ke-2, 3 dan 4 dan berpengaruh tidak nyata $(p>0,05)$ pada minggu ke-1. Interaksi kedua perlakuan berpengaruh sangat nyata $(\mathrm{p}<0,01)$ pada minggu ke-2, 3 dan 4 serta berpengaruh tidak nyata $(\mathrm{p}>0,05)$ pada minggu ke-1. Rata-rata nilai kemerahan $\left(a^{*}\right)$ ekstrak alga merah Gracilaria sp. tiap minggunya dapat dilihat pada Tabel 3 .

Tabel 3. Rata-rata nilai kemerahan ( $\left.a^{*}\right)$ ekstrak alga merah Gracilaria sp. dan laju penurunan nilai kemerahan pada perlakuan $\mathrm{pH}$ dan suhu penyimpanan pada minggu ke-1 sampai minggu ke4.

\begin{tabular}{|c|c|c|c|c|c|c|}
\hline \multicolumn{4}{|c|}{ Minggu ke-1 } & \multicolumn{3}{|c|}{ Minggu ke-2 } \\
\hline \multirow{2}{*}{$\mathrm{pH}$} & \multicolumn{2}{|c|}{ Suhu } & \multirow{2}{*}{ Rata-rata \pm SD } & \multirow{2}{*}{$\mathrm{pH}$} & \multicolumn{2}{|c|}{ Suhu } \\
\hline & $4 \pm 2^{\circ}$ & $28 \pm 2^{\circ} \mathrm{C}$ & & & $4 \pm 2^{\circ} \mathrm{C}$ & $28 \pm 2^{\circ} \mathrm{C}$ \\
\hline 4 & 20,42 & 20,65 & $20,535 \pm 0,278^{a}$ & 4 & $20,03 \pm 0,24^{\mathrm{ab}}$ & $20,15 \pm 0,27^{\mathrm{a}}$ \\
\hline 7 & 20,22 & 20,79 & $20,505 \pm 0,356^{\mathrm{a}}$ & 7 & $20,11 \pm 0,43^{\mathrm{ab}}$ & $19,20 \pm 0,47^{\mathrm{b}}$ \\
\hline 10 & 20,51 & 20,35 & $20,430 \pm 0,113^{a}$ & 10 & $19,03 \pm 0,47^{\mathrm{b}}$ & $14,29 \pm 0,08^{\mathrm{c}}$ \\
\hline Rata-rata \pm SD & $\begin{array}{c}20,38 \pm \\
0,321^{\mathrm{a}}\end{array}$ & $\begin{array}{c}20,59 \pm \\
0,245^{\mathrm{a}}\end{array}$ & & & & \\
\hline \multicolumn{4}{|c|}{ Minggu ke-3 } & \multicolumn{3}{|c|}{ Minggu ke-4 } \\
\hline \multirow{2}{*}{$\mathrm{pH}$} & \multicolumn{3}{|c|}{ Suhu } & \multirow{2}{*}{$\mathrm{pH}$} & \multicolumn{2}{|c|}{ Suhu } \\
\hline & $4 \pm 2$ & & $28 \pm 2^{\circ} \mathrm{C}$ & & $4 \pm 2^{\circ} \mathrm{C}$ & $28 \pm 2^{\circ} \mathrm{C}$ \\
\hline 4 & 19,38 & & $18,20 \pm 0,04^{b}$ & 4 & $19,30 \pm 0,16^{a}$ & $17,12 \pm 0,15^{\mathrm{c}}$ \\
\hline 7 & 10,52 & & $16,92 \pm 0,07^{c}$ & 7 & $17,72 \pm 0,32^{b}$ & $17,10 \pm 0,39^{c}$ \\
\hline 10 & $18,48=$ & & $10,84 \pm 0,33^{\mathrm{d}}$ & 10 & $10,72 \pm 0,11^{\mathrm{d}}$ & $9,70 \pm 0,35^{\mathrm{e}}$ \\
\hline
\end{tabular}

Keterangan: Angka yang diikuti huruf yang berbeda pada kolom yang sama menunjukan berbeda nyata $(\mathrm{P}<0,05)$. Data merupakan rata-rata dari tiga ulangan pada masing-masing perlakuan

Persentase nilai kemerahan $\left(a^{*}\right)$ ekstrak alga merah Gracilaria sp. selama penyimpanan pada masing-masing perlakuan mengalami penurunan setiap minggunya. Nilai kemerahan ekstrak Gracilaria sp. menurun seiring dengan penurunan kadar fikoeritrin setiap minggunya. Pada minggu ke-1 nilai kemerahan ekstrak Gracilaria sp. tidak mengalami perbedaan pada perlakuan $\mathrm{pH}$ dan perlakuan suhu. Pada minggu ke-2 perlakuan $\mathrm{pH} 4$ pada $28 \pm 2^{\circ} \mathrm{C}$ tidak berbeda nyata dengan perlakuan pH 4 dan 7 pada suhu $4 \pm 2^{\circ} \mathrm{C}$, tetapi berbeda nyata pada perlakuan $\mathrm{pH} 10$ pada suhu $28 \pm 2^{\circ} \mathrm{C}$. Pada minggu ke-3 dan 4 nilai kemerahan $\left(a^{*}\right)$ mengalami perbedaan pada setiap perlakuannya dan perlakuan $\mathrm{pH} 10$ pada suhu $28 \pm 2^{\circ} \mathrm{C}$ memiliki nilai kemerahan terkecil. Hal ini sesuai dengan penelitian Yulianti et al. (2015) bahwa semakin besar nilai tingkat kemerahan $\left(a^{*}\right)$ menunjukkan kecenderungan warna yang semakin merah dan sebaliknya, semakin kecil nilai tingkat 
kemerahan menunjukkan kecenderungan warna yang semakin hijau. Maka semakin tinggi nilai kemerahan akan menghasilkan pewarna alami yang semakin baik. Nilai kemerahan $\left(a^{*}\right)$ yang tinggi menunjukkan bahwa kadar pigmen fikoeritrin stabil pada penyimpan tersebut. Perlakuan $\mathrm{pH} 10$ pada suhu $28 \pm 2^{\circ} \mathrm{C}$ menunjukkan penurunan nilai kemerahan $\left(a^{*}\right)$ terbesar dibanding dengan perlakuan lainnya yaitu sebesar $53,04 \%$. Hal ini menunjukkan bahwa pigmen fikoeritrin pada ekstrak alga merah Gracilaria sp. tidak stabil pada perlakuan tersebut.

\section{Tingkat Kekuningan $(b *)$}

Nilai kekuningan minggu ke-0 pada ekstrak pewarna dari alga merah Gracilaria sp. yang diperoleh adalah sebesar 11,30. Analisis ragam untuk nilai kekuningan $\left(b^{*}\right)$ menunjukkan bahwa perlakuan $\mathrm{pH}$ berpengaruh sangat nyata $(\mathrm{p}<0,01)$ pada minggu ke-2, 3 dan 4 serta berpengaruh tidak nyata $(p>0,05)$ pada minggu ke- 1 . Perlakuan suhu berpengaruh sangat nyata $(\mathrm{p}<0,01)$ pada minggu ke-2, 3 dan 4 serta berpengaruh tidak nyata $(\mathrm{p}>0,05)$ pada minggu ke-1. Interaksi kedua perlakuan berpengaruh sangat nyata $(\mathrm{p}<0,01)$ pada minggu ke-2, 3 dan 4 serta tidak nyata $(\mathrm{p}>0,05)$ pada minggu ke-1. Rata-rata nilai kekuningan $\left(b^{*}\right)$ ekstrak alga merah Gracilaria sp. tiap minggunya dapat dilihat pada Tabel 4.

Tabel 4. Rata-rata nilai kekuningan $\left(b^{*}\right)$ ekstrak alga merah Gracilaria sp. dan laju kenaikan nilai kekuningan pada perlakuan $\mathrm{pH}$ dan suhu penyimpanan pada minggu ke-1 sampai minggu ke-4

\begin{tabular}{|c|c|c|c|c|c|c|}
\hline \multicolumn{4}{|c|}{ Minggu ke-1 } & \multicolumn{3}{|c|}{ Minggu ke-2 } \\
\hline \multirow{2}{*}{$\mathrm{pH}$} & \multicolumn{2}{|c|}{ Suhu } & \multirow{2}{*}{ Rata-rata \pm SD } & \multirow{2}{*}{$\mathrm{pH}$} & \multicolumn{2}{|c|}{ Suhu } \\
\hline & $4 \pm 2^{\circ}$ & $28 \pm 2^{\circ} \mathrm{C}$ & & & $4 \pm 2^{\circ} \mathrm{C}$ & $28 \pm 2^{\circ} \mathrm{C}$ \\
\hline 4 & 11,44 & 11,64 & $11,545 \pm 0,132^{a}$ & 4 & $11,52 \pm 0,13^{b}$ & $11,78 \pm 0,25^{b}$ \\
\hline 7 & 11,57 & 11,52 & $11,545 \pm 0,227^{\mathrm{a}}$ & 7 & $11,55 \pm 0,40^{\mathrm{b}}$ & $11,81 \pm 0,20^{\mathrm{b}}$ \\
\hline 10 & 11,52 & 12,02 & $11,777 \pm 0,360^{\mathrm{a}}$ & 10 & $11,44 \pm 0,12^{b}$ & $13,70 \pm 0,23^{\mathrm{a}}$ \\
\hline Rata-rata \pm SD & $\begin{array}{c}11,52 \pm \\
0,167^{\mathrm{a}}\end{array}$ & $\begin{array}{c}11,73 \pm \\
0,312^{\mathrm{a}}\end{array}$ & & & & \\
\hline \multicolumn{4}{|c|}{ Minggu ke-3 } & \multirow{2}{*}{\multicolumn{3}{|c|}{$\begin{array}{c}\text { Minggu ke-4 } \\
\text { Suhu }\end{array}$}} \\
\hline \multirow{2}{*}{$\mathrm{pH}$} & \multicolumn{3}{|c|}{ Suhu } & & & \\
\hline & $4 \pm 2$ & & $28 \pm 2^{\circ} \mathrm{C}$ & $\mathrm{pH}$ & $4 \pm 2^{\circ} \mathrm{C}$ & $28 \pm 2^{\circ} \mathrm{C}$ \\
\hline 4 & 11,60 & & $12,30 \pm 0,04^{\mathrm{bc}}$ & 4 & $11,71 \pm 0,07^{\mathrm{e}}$ & $13,04 \pm 0,44^{\mathrm{c}}$ \\
\hline 7 & 12,04 & & $12,82 \pm 0,67^{b}$ & 7 & $12,60 \pm 0,22^{\mathrm{d}}$ & $14,11 \pm 0,16^{b}$ \\
\hline 10 & $12,40 \pm$ & & $14,47 \pm 0,19^{a}$ & 10 & $13,04 \pm 0,10^{\mathrm{c}}$ & $15,54 \pm 0,03^{\mathrm{a}}$ \\
\hline
\end{tabular}

Keterangan: Angka yang diikuti huruf yang berbeda pada kolom dan baris yang sama menunjukan berbeda nyata $(\mathrm{P}<0,05)$. Data merupakan rata-rata dari tiga ulangan pada masing-masing perlakuan

Persentase nilai kekuningan $\left(b^{*}\right)$ ekstrak alga merah Gracilaria sp. selama penyimpanan pada masing-masing perlakuan mengalami kenaikan setiap minggunya. Nilai kekuningan meningkat seiring dengan penurunan kadar fikoeritrin pada setiap minggunya. Pada minggu ke-1 tidak terjadi perubahan pada perlakuan $\mathrm{pH}$ dan suhu tetapi pada $\mathrm{pH} 10$ memiliki tingkat kekuningan yang tertinggi. Pada minggu ke-2, ke-3 dan ke-4 perlakuan $\mathrm{pH} 10$ pada suhu $28 \pm 2^{\circ} \mathrm{C}$ mengalami perbedaan nyata dengan perlakuan lainnya. Perlakuan $\mathrm{pH} 10$ pada suhu $28 \pm 2^{\circ} \mathrm{C}$ menunjukkan kenaikan nilai kekuningan $\left(b^{*}\right)$ terbesar dibanding dengan perlakuan lainnya yaitu sebesar $27,18 \%$. Hal ini menunjukkan bahwa perlakuan ekstrak alga merah Gracilaria sp. tidak stabil pada perlakuan tersebut. Hal ini sesuai dengan penelitian Naga et al. (2010) dan Kawsar et al. (2011) yang menyatakan bahwa pigmen fikoeritrin akan mengalami perubahan warna karena denaturasi protein pada saat keadaan $\mathrm{pH}$ dibawah dari 3 dan lebih dari 10. 


\section{KESIMPULAN DAN SARAN}

Kesimpulan

Berdasarkan penelitian yang telah

dilakukan maka diperoleh kesimpulan sebagai berikut:

1. Perlakuan $\mathrm{pH}$ dan suhu sangat berpengaruh pada setiap minggunya terhadap stabilitas ekstrak alga merah Gracilaria sp. sebagai

pewarna alami. Perlakuan $\mathrm{pH}$ sangat berpengaruh terhadap kadar total

fikoeritrin, tingkat kecerahan $\left(\mathrm{L}^{*}\right)$, tingkat kemerahan $\left(\mathrm{a}^{*}\right)$ dan tingkat kekuningan (b*) pada minggu ke-2, 3, 4. Perlakuan suhu sangat berpengaruh terhadap kadar total fikoeritrin dan tingkat kecerahan $\left(\mathrm{L}^{*}\right)$ pada minggu ke-3 dan 4 , serta tingkat kemerahan $\left(\mathrm{a}^{*}\right)$, dan tingkat kekuningan (b*) pada minggu ke-2, 3, dan 4. Pada minggu ke-1 dan ke-2 kadar fikoeritrin masih sama baik pada $\mathrm{pH} 4$ dan $\mathrm{pH} 7$ tetapi mulai berbeda pada minggu ke-4. Tingkat kecerahan, tingkat kemerahan dan tingkat kekuningan pada $\mathrm{pH} 4$ dan $\mathrm{pH} 7$ tidak berbeda pada minggu ke- 1 dan ke- 2 tetapi terjadi perbedaan pada minggu ke- 3 .

2. Perlakuan $\mathrm{pH} 4$ dan suhu dingin $\left(4 \pm 2^{\circ} \mathrm{C}\right)$ merupakan perlakuan terbaik untuk mempertahankan stabilitas ekstrak alga merah Gracilaria sp. sampai pada minggu ke-4 karena memiliki penurunan kadar fikoeritrin dan tingkat kemerahan $\left(\mathrm{a}^{*}\right)$ terkecil, serta memiliki kenaikan tingkat kecerahan $\left(\mathrm{L}^{*}\right)$ dan tingkat kekuningan (b*) terkecil. Persentase penurunan kadar fikoeritrin, kenaikan nilai kecerahan $\left(\mathrm{L}^{*}\right)$, penurunan nilai kemerahan $\left(a^{*}\right)$ dan kenaikan nilai kekuningan $\left(b^{*}\right)$ berturutturut adalah $13,04 \%, 0,47 \%, 6,58 \%$, dan $3,50 \%$.

\section{Saran}

1. Perlu dilakukan penelitian lebih lanjut mengenai perubahan struktur senyawa fikoeritrin akibat degradasi dan perlu dilakukan analisis senyawa yang dihasilkan dari proses degradasi ekstrak alga merah Gracilaria sp. selama penyimpanan.

2. Ekstrak pewarna dari alga merah Gracilaria sp. sebaiknya disimpan pada penyimpanan suhu dingin dan sebaiknya diaplikasikan pada produk yang memiliki karakteristik pH asam.

\section{DAFTAR PUSTAKA}

Agustini, T. W. 2013. Penentuan total antosiani daari kelopak bunga rosella (Hibiscus sadbariffa L.) dengan metode maserasi dan soxletasi. Jurnal sains dan matematika. 8 (2): 167 177.

Alamsjah, M., N. O. Ayuningtiaz, dan S. Subekti. 2010. Pengaruh lama penyinaran terhadap pertumbuhan dan klorofil Gracilaria verrucosa pada sistem budidaya indoor. Jurnal ilmiah Perikanan dan Kelautan. 2 (1): 21-29.

Claire, C. 1992. De la création d'une banque de données sur la composition biochimique des algues aux résultats d'une investigation systématique: un colorant naturel stable issu d'une Rhodophycée. PhD Thesis. Université de Nantes, Nantes.

D’Agnolo, E., E. Murano., R. Rizzo., and S. Paoletti. 1993. A biliprotein from the red alga Gracilaria longa: Thermal stability of R-phycoerythrin. Italian Journal of Biochemistry. 42: $316-$ 318.

Galland-Irmouli, A.-V. Pons., L. Lucon., M. Villaume., C. Mrabet., N. T. Gueant., 2000. One step purification of Rphycoerythrin from the red macroalga Palmaria palmate using preparative polyacrylamide gel electrophoresis. 
Journal of Chromatography B. 739: $117-123$.

Gaman, P.M., dan K. B Sherington. 1992. Ilmu Pangan: Pengantar Ilmu Pangan, Nutrisi, dan Mikrobiologi. Gardjito, M. (Penerjemah) dan Kasmidjo, R.B. (Penyunting). Gadjah Mada University Press, Yogyakarta.

Gross, J. 1991. Pigment in Vegetables (Chlorophylls and Carotenoids). Van Norstran Reinhold, New York.

Indrayati, F., R. Utami, dan E. Nurhartadi. 2013. Pengaruh penambahan minyak atsiri kunyit putih (Kaempferia rotunda) pada edible coating terhadap stabilitas warna dan $\mathrm{pH}$ fillet ikan patin yang disimpan pada suhu beku. Jurnal Teknosains Pangan. 4 (2): suhu beku. Jurnal Teknosains Pangan. 4 (2): $25-31$.

Indriyani, N. M. D., N. M. Wartini, dan N. P. Suwariani. 2018. Stabilitas karotenoid ekstrak pewarna buah pandan (Pandanus tectorius) pada suhu dan $\mathrm{pH}$ awal penyimpanan. Jurnal Rekayasa dan Manajemen Agroindustri. 6 (3): 211-217.

Karseno., I. Handayani., R. Setyawati. 2013. Aktivtas dan stabilitas antioksidan ekstrak pigmen alga Oscillatoria sp. Agritech. 33 (4): 371 - 376.

Kawsar, S. M., Y. Fujii, R. Matsumoto, H. Yasumitsu, and Y. Ozeki. 2011. Protein R-phycoerythrin from marine red alga Amphiroa anceps: extraction, purification and characterization. Phyotologia balcanica. 17 (3): 341 354.

Liu, L. N., H. N. Su., S. G. Yang., S. M. Shao., B. B. Xhie., X. L. Chen. 2009. Probling the $\mathrm{pH}$ sensitivy of $\mathrm{R}$ phycoerythrin: Investigations of active conformational and functional variation. Biochimica et Biophysica Acta (BBA) - Bioenergetics. 1797 (7): $939-946$.

Naga, W. S., B. Adiguna, E. S. Retnoningtyas, dan A. Ayucitra. 2010. Koagulasi protein dari ekstrak biji kecipir dengan metode pemanasan. Jurnal imliah Widya Teknik. 9 (1): 1-11.

Niu, J. F., G. C. Wang, and C. K. Tseng. 2006. Method for large scale isolation and puficitaion of r-phycoerithtrin form red alga Polysiphonia erceolata grev. Journals Protein Expression and Purification. 49 (1): 23-31.

Orta-Raminez, A., J. E. Merrill., and D. M. Smith. 2000. pH affects the thermal inactivation parameters of $\mathrm{R}$ phycoerythrin from Porphyra yezoensis. Journal of Food Science. 65 (6): 1046 - 1050.

Romay, C. 2000. Phycocyanin is an antioxidant protector of human erythrocytes against lysis by peroxyl radicals. Journal of Pharmacy and Pharmacology. 52 (4): 367-368.

Rossnano, R., N. Ungaro., A. D’Ambrosio., and P. Riccio. 2003. Extracting and purifying R-phycoerythrin from Mediterranean red algae Corallina elongate Ellis \& Solander. Journal of Biotechnology. 101: 289 - 293.

Sajilata dan Singhal, 2006. Isolation and Stabilitation of Natural Pigments for Food Application. Stewart Postharvest Review. 2 (5): 5 - 11.

Septiana, A. T., dan A. Asnani. 2012. Kajian sifat fisikokimia ekstrak rumput laut coklat Sargassum duplicatum menggunakan berbagai pelarut dan metode ekstrasi. Agointek. 6 (1): $22-$ 28.

Siegelman, H. W., and H. J. Kycia. 1978. 
Algal Biliproteins: Handbook of Phycological Method. Cambridge Press, Cambridge

Silveira, S. T., J. F. M. Bukerts, J. A. V. Costa, C. A. V. Burkert, and S. J. Kalil. 2007. Optimization od phycocyanin extraction from Spirulina splatensis using factorial design. Bioresource Technology. 98: 1629-1634.

Sudhakar, M. P., M. Saraswathi, and B. B. Nair. 2014. Extraction, purification and application study of RPhycoerythrin from Gracilaria corticala (J. Agardh) J. Agardh var. Corticata. Indian Journal of Natural Products and Resources. 5 (4): 371374.
Suhartono, T. S., dan S. L. Angka. 2000. Bioteknologi Hasil Laut, Bogor: Pusat kajian sumber daya pesisir dan lautan. Institus Pertanian Bogor. 49 - 56.

Weaver, C. 1996. The Food Chemistry Laboratory. CRS Press, New York.

Yulianti, Y.W., M.A. Alamsjah dan P.H. Riesta. 2015. Pigmen rumput laut merah (Acanthopora spicifera) sebagai alternatif pewarna alami pada produk sosis ikan lele dumbo (Clarias gariepinus). Jurnal Ilmiah Perikanan dan Kelautan. 7 (1): 47 - 5. 